\title{
Decision Factors for Purchasing Local Cosmetic Products
}

\author{
Siska Martarahayu* Agus Hermawan Agung Winarno \\ State University of Malang, Address: Jalan Semarang 5, Lowokwaru Sub-district, Malang City, East Java, \\ Indonesia
}

\begin{abstract}
Currently Indonesian local cosmetics are experiencing rapid development, many local cosmetics producers are emerging and products that are issued do not compete with global cosmetic products. Local cosmetics are also starting to be in demand by consumers in Indonesia. This study aims to explore the cosmetic purchasing decisions of Make Over. This study uses exploratory factor analysis with a total sample of 135 respondents who have made Make Over products. The results of this study formed seven factors that make the purchase of Make Over products and motivational factors are the dominant factors that are the product purchasing decision factors. This research is expected to add insight into consumer behavior.
\end{abstract}

Keywords: Purchasing Factors, Cosmetics, Purchasing Decisions

DOI: $10.7176 / \mathrm{EJBM} / 11-21-12$

Publication date:July $31^{\text {st }} 2019$

\section{Introduction}

At present Indonesia is one of the large cosmetics markets. This is evidenced by, the national cosmetics industry noted an increase of $20 \%$ or four times the growth of the national economy in 2017 . The cosmetic industry in Indonesia increased by 153 companies in 2017, so there are currently 760 cosmetic companies. The increase in growth was driven because there was considerable demand from both the domestic and export markets. The Ministry of Industry said that several local cosmetics producers have been able to export their products abroad such as to ASEAN, Africa, the Middle East and others. In 2017, the export value of local cosmetic products reached US \$ 516.99 million, up from US \$ 470.30 million in 2016. The Ministry of Industry has placed the cosmetics industry as a mainstay sector as stated in the 2015-2035 National Industrial Development Master Plan (RIPIN). (www.kemenperin.go.id).

Cosmetic products are products that are used by consumers to meet their own needs. Kotler (2007) explains that consumer goods are goods consumed for the benefit of the end consumers themselves not for business purposes. In general, consumer goods are divided into four types, namely Convenience Gods, Special Goods, Shopping Goods, Unsought Goods. Cosmetic products are included in the category of Special Goods, namely goods or products that have the characteristics and identification of unique brands where consumers are willing to make a special effort to buy them. Consumers generally provide a separate budget for buying cosmetic products.

Minister of Industry, Airlangga Hartato (kompas.com) revealed that local spa products are quite attractive to foreign tourists. The government hopes that with good branding, it is hoped that national cosmetic products can achieve success such as cosmetic products from South Korea. Nowadays cosmetics from Korea are much loved by the people of Indonesia and even the world. Millennials are also an important key in cosmetic marketing innovations, namely through more effective and inexpensive social media. In Korea, producers and governments consistently provide cosmetic packages as souvenirs, while in Indonesia they have not. In Indonesia there are not many tourists attractions that offer cosmetics as souvenirs. The government revealed that local cosmetics can imitate the marketing strategy so that the local cosmetics industry can succeed in their own country.

At the moment Indonesian local cosmetics are experiencing rapid development, many local cosmetics producers have sprung up and products that have been released have not competed with global cosmetic products. Local cosmetics are also starting to be in demand by consumers in Indonesia. There are many local cosmetic brands in Indonesia, one of which is MAKE OVER. MAKE OVER is a cosmetic brand from PT. Paragon Technology and Innovation (PTI) which has been around for 8 years. MAKE OVER is often said to be a product from abroad. This is because MAKE OVER packaging that looks elegant and has premium quality compared to other PTI products. In terms of price, MAKE OVER products are more expensive than Wardah and Emina products, besides MAKE OVER products are widely used by MUA (makeup artists). MAKE OVER has a fairly complete variant, ranging from primary makeup, shape and cover, finishing makeup, eye decorative color, eye definer, decorative color cheek, lip decorative color, care and treat, and cosmetic equipment. Currently MAKE OVER has been promoting by using advertisements on TV, before MAKE OVER used a promotional strategy through a fashion show.

\section{Literature Review}

2.1 Purchase Decision

Consumer decisions to buy or not a product is important for marketers, therefore marketers must pay attention to 
aspects of purchasing decisions. According to Kotler (2009) to arrive at the purchase stage, there are several steps in the purchasing process. The decision-making process includes the following stages, problem recognition, information seeking, alternative evaluation, purchasing decisions, and post-purchase behavior.

\subsection{Factors Affecting Purchasing Decisions}

There are consumer characteristics, which encourage consumers to make decision-making processes to buy products so that consumers get the benefits of the products purchased. Consumer characteristics, can be referred to as factors that influence consumer behavior in making purchases. According to Berkowitz, et al (1989) the factors that influence consumer decisions in making purchases include psychological factors, situation factors, socio-cultural factors and marketing mix factors.

\subsection{Consumer Behavior}

Understanding consumer behavior according to experts varies, one of them according to Kotler (2007), which says that consumer behavior is the study of the ways individuals, groups, and organizations select, buy, use, and dispose of goods, services, ideas or experiences to satisfy consumer needs and desires. The study of consumers provides instructions for introducing and improving products, setting prices, planning channels, arranging messages, and developing other marketing activities. Manufacturers must know the needs and desires of consumers, by knowing the needs and desires of consumers for a product, the producer can influence consumers so they want to buy their products. American Marketing Association in Wardana (2011) explains that consumer behavior is a dynamic interaction between influence and cognition, behavior and events around us in which humans exchange in their lives.

\section{Methodology and Research}

This research is classified into ex post facto research with a quantitative approach, namely observing events that have already occurred and the factors considered in the variables observed using exploratory factor analysis

\subsection{Population}

The population in this study is an unlimited number of consumers of Make Over local cosmetic products, so it is an infinite population.

\subsection{Sample}

The sample in this study was taken using purposive sampling technique. The consideration is that the respondent is a student of the UB Faculty of Administrative Sciences who has used local cosmetics. Maholtra (2006) states that marketing research must be at least four or five times the number of question items. This study contained 24 items of questions, so the researchers decided the number of samples was 27 x $5=135$ respondents / people who would be used as research samples.

\subsection{Data Analysis Techniques}

Data analysis in this study uses factor analysis techniques. Hair et al (2010), said that factor analysis is an interdependence technique whose main goal is to determine the underlying structure among the variables in the analysis.

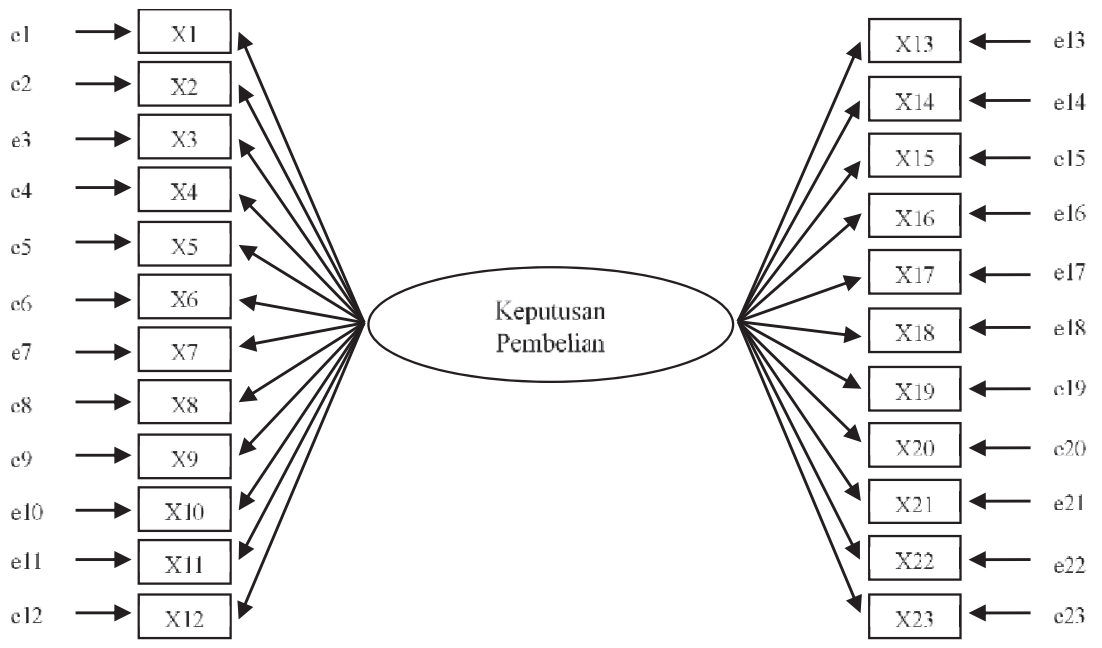

Figure 1. Design of Research 
Information:

$$
\begin{array}{ll}
\text { e1 }- \text { en }=\text { error } & \text { X8 }=\text { Friend } \\
\text { X1 }=\text { Trend } & \text { X9 }=\text { Beauty Blogger } \\
\text { X2 }=\text { Self-confidence } & \text { X10 }=\text { Review web } \\
\text { X3 }=\text { Need to look beautiful } & \text { X11 }=\text { Varian Product } \\
\text { X4 }=\text { Luminous skin } & \text { X12 }=\text { Packaging design } \\
\text { X5 }=\text { Suitable on the skin } & \text { X13 }=\text { Practicality } \\
\text { X6 }=\text { Price } & \text { X14 }=\text { Safe on the skin } \\
\text { X7 = Family } & \text { X15 = Ease of getting }
\end{array}
$$

$\mathrm{X} 16=$ Display of outlets

$\mathrm{X} 17=$ Arrangement of outlets

$\mathrm{X} 18=$ Advertisements

$\mathrm{X} 19=$ Intensity of broadcast ads

\begin{tabular}{|c|c|c|c|c|c|c|}
\hline \multirow[b]{2}{*}{ Component } & \multicolumn{3}{|c|}{ Initial Eigenvalues } & \multicolumn{3}{|c|}{ Extraction Sums of Squared Loadings } \\
\hline & Total & $\%$ of Variance & Cumulative \% & Total & $\%$ of Variance & Cumulative \% \\
\hline 1 & 6.880 & 28.666 & 28.666 & 6.880 & 28.666 & 28.666 \\
\hline 2 & 2.562 & 10.675 & 39.341 & 2.562 & 10.675 & 39.341 \\
\hline 3 & 1.807 & 7.530 & 46.871 & 1.807 & 7.530 & 46.871 \\
\hline 4 & 1.651 & 6.877 & 53.748 & 1.651 & 6.877 & 53.748 \\
\hline 5 & 1.369 & 5.704 & 59.453 & 1.369 & 5.704 & 59.453 \\
\hline 6 & 1.196 & 4.981 & 64.434 & 1.196 & 4.981 & 64.434 \\
\hline 7 & 1.026 & 4.275 & 68.709 & 1.026 & 4.275 & 68.709 \\
\hline 8 & .850 & 3.541 & 72.250 & & & \\
\hline 9 & .791 & 3.297 & 75.547 & & & \\
\hline 10 & .719 & 2.995 & 78.542 & & & \\
\hline 11 & .642 & 2.674 & 81.217 & & & \\
\hline 12 & .617 & 2.570 & 83.786 & & & \\
\hline 13 & .528 & 2.202 & 85.988 & & & \\
\hline 14 & .475 & 1.979 & 87.967 & & & \\
\hline 15 & .430 & 1.794 & 89.761 & & & \\
\hline 16 & .417 & 1.736 & 91.496 & & & \\
\hline 17 & .387 & 1.614 & 93.110 & & & \\
\hline 18 & .345 & 1.438 & 94.548 & & & \\
\hline 19 & .303 & 1.262 & 95.811 & & & \\
\hline 20 & .262 & 1.093 & 96.904 & & & \\
\hline 21 & .206 & .857 & 97.761 & & & \\
\hline 22 & .192 & .801 & 98.562 & & & \\
\hline 23 & .187 & .780 & 99.342 & & & \\
\hline
\end{tabular}

$\mathrm{X} 20=$ Brand Ambassador

$\mathrm{X} 21=$ Sponsor

$\mathrm{X} 22=$ Discount

$\mathrm{X} 23=$ Testers

\section{Result}

4.1 Testing Assumptions for Factor Analysis

Table 1. Results for KMO and Bartlett's Test

KMO and Bartlett's Test

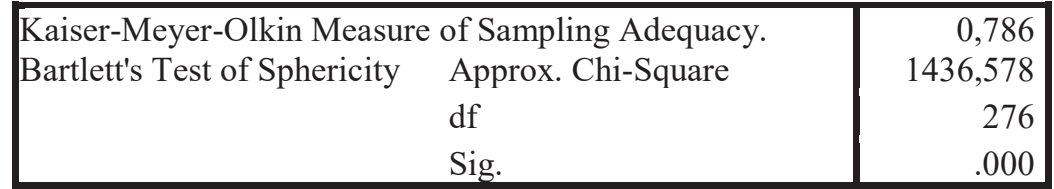

The table above is a table of results from testing assumptions of factor analysis. The KMO and Bartlett's Test number is 0.786 with a significance of 0,000 . This shows that the KMO and Bartlett's Test numbers are above 0.05 and the significance is 0,000 ( $\mathrm{sig}<0.05$ ), so the variables can be further analyzed.

4.2 Extracting Method and Determining the Number of Factors

Figure 2. Table Total Variance Explained

In the Figure above shows that there are 7 factors formed from a number of indicators used. Factor 1 shows the variation of the data is $28.666 \%$, factor 2 is $10.675 \%$, factor 3 is $7.530 \%$, factor 4 is $6.877 \%$, factor 5 is $5.704 \%$, factor 6 is 4.981, and factor 7 is $4.275 \%$. In the Initial Eigenvalues section, it shows that 7 factors formed have Eigenvalues $>1$, so that these factors are used. 


\subsection{Loading Factor Results}

Table 2. Rotated Component Matrix

\begin{tabular}{|c|c|c|c|c|c|c|c|}
\hline & \multicolumn{7}{|c|}{ Component } \\
\hline & 1 & 2 & 3 & 4 & 5 & 6 & 7 \\
\hline V1 & $-0,004$ & 0,065 & 0,085 & $-0,073$ & 0,011 & 0,137 & 0,866 \\
\hline $\mathrm{V} 2$ & 0,118 & $-0,068$ & $-0,001$ & 0,240 & $-0,148$ & $-0,353$ & 0,630 \\
\hline V3 & 0,750 & 0,042 & 0,015 & 0,295 & 0,064 & 0,079 & 0,055 \\
\hline V4 & 0,773 & $-0,063$ & $-0,023$ & 0,140 & 0,171 & 0,206 & 0,146 \\
\hline V5 & 0,774 & 0,274 & 0,056 & 0,117 & $-0,035$ & 0,075 & $-0,002$ \\
\hline V6 & 0,312 & 0,533 & $-0,212$ & 0,131 & 0,475 & 0,016 & 0,036 \\
\hline V7 & 0,220 & 0,266 & 0,300 & $-0,004$ & $-0,268$ & 0,650 & 0,006 \\
\hline V8 & 0,097 & 0,159 & 0,108 & 0,176 & 0,081 & 0,833 & $-0,032$ \\
\hline V9 & 0,115 & 0,211 & $-0,031$ & 0,711 & 0,224 & 0,277 & 0,056 \\
\hline V10 & 0,180 & 0,146 & 0,079 & 0,686 & 0,298 & $-0,001$ & 0,075 \\
\hline V11 & 0,453 & 0,171 & 0,152 & 0,539 & $-0,013$ & $-0,067$ & $-0,064$ \\
\hline V12 & 0,003 & 0,738 & 0,117 & 0,304 & 0,047 & 0,136 & $-0,052$ \\
\hline V13 & 0,157 & 0,646 & 0,166 & 0,353 & 0,024 & $-0,140$ & $-0,061$ \\
\hline V14 & 0,615 & 0,152 & 0,319 & $-0,056$ & 0,161 & $-0,042$ & $-0,093$ \\
\hline V15 & 0,420 & 0,183 & $-0,013$ & $-0,143$ & 0,642 & $-0,188$ & 0,067 \\
\hline V16 & 0,152 & 0,752 & 0,244 & $-0,073$ & 0,071 & 0,134 & 0,092 \\
\hline V17 & 0,075 & 0,774 & 0,168 & 0,046 & 0,019 & 0,314 & 0,032 \\
\hline V18 & 0,202 & 0,215 & 0,678 & $-0,048$ & 0,260 & 0,045 & $-0,038$ \\
\hline V19 & $-0,050$ & 0,179 & 0,756 & $-0,132$ & 0,157 & 0,262 & 0,113 \\
\hline V20 & 0,037 & 0,099 & 0,770 & 0,362 & $-0,195$ & $-0,002$ & $-0,030$ \\
\hline V21 & 0,178 & 0,132 & 0,617 & 0,370 & 0,157 & 0,156 & 0,171 \\
\hline $\mathrm{V} 22$ & 0,158 & 0,038 & 0,144 & 0,340 & 0,714 & 0,049 & $-0,167$ \\
\hline V23 & $-0,094$ & $-0,010$ & 0,236 & 0,290 & 0,789 & 0,046 & $-0,023$ \\
\hline
\end{tabular}

In the table above, shows the results of the rotation process of component matrix (rotated component matrix). In table 2 the factors formed have been identified, besides that there have been variable divisions according to factors. The numbers in the table show the magnitude of the correlation between variables and the factors that exist. Variables that are highly correlated with factors are indicated by high loading factor values.

A total of 7 factors have been formed, more details will be described in the results table and naming new factors below:

Table 3. Results and Naming of New Factors

\begin{tabular}{|c|c|c|c|c|c|c|}
\hline $\begin{array}{c}\text { Factor } 1 \\
\text { Perception of } \\
\text { Product } \\
\text { Benefits }\end{array}$ & $\begin{array}{l}\text { Factor } 2 \\
\text { Product }\end{array}$ & $\begin{array}{c}\text { Factor } 3 \\
\text { Promotion }\end{array}$ & $\begin{array}{c}\text { Factor } 4 \\
\text { Social } \\
\text { Media }\end{array}$ & $\begin{array}{l}\text { Factor } 5 \\
\text { Service }\end{array}$ & $\begin{array}{c}\text { Factor } 6 \\
\text { Recommen- } \\
\text { dation }\end{array}$ & $\begin{array}{c}\text { Factor } 7 \\
\text { Trend }\end{array}$ \\
\hline $\begin{array}{l}\text { The need for } \\
\text { beauty } \\
\text { Luminous skin } \\
\text { Safe for skin } \\
\text { Suitable on the } \\
\text { skin }\end{array}$ & $\begin{array}{l}\text { Design } \\
\text { Practicality } \\
\text { Outlets } \\
\text { Outlet } \\
\text { arrangement }\end{array}$ & $\begin{array}{l}\text { Advertising } \\
\text { Advertising } \\
\text { intensity } \\
\text { Brand } \\
\text { ambassador } \\
\text { Sponsorship }\end{array}$ & $\begin{array}{l}\text { Beauty } \\
\text { Blogger } \\
\text { Review }\end{array}$ & $\begin{array}{l}\text { Ease of } \\
\text { getting } \\
\text { products } \\
\text { Discount } \\
\text { Tester }\end{array}$ & $\begin{array}{l}\text { Family } \\
\text { Friends }\end{array}$ & $\begin{array}{l}\text { Trend } \\
\text { Self- } \\
\text { confidence }\end{array}$ \\
\hline
\end{tabular}

\section{Discussion}

5.1. Make Over's Product Purchase Decision Factors

Based on the results of the study, that of the 23 items used in the study seven factors were considered in the decision to purchase Make Over products, namely:

5.1.1 1. Perception of Product Benefits

The results of the analysis show that the perceptions of the benefits of this product are formed from several variables, namely the need to look beautiful, the skin looks glowing (healthy), suitable for the skin, and safe for the skin. Ferrinadewi (2008) said in his research that perception is a process in which various stimuli are chosen, organized, and interpreted as meaningful information. The perception of product benefits here is the interpretation of consumers of the benefits of using Make Over products. Consumers in making decisions to buy Make Over products consider the benefits of the products obtained for their skin and appearance.

Perception of the benefits of self-oriented products to meet the needs, desires and internal satisfaction of consumers (Milfelner, 2017). Consumers feel they will get various benefits when they decide to buy Make Over 
products. Suitable on the skin is the most dominant variable from the perception factor of benefits in this study. Consumers choose Make Over products because the products offered can be used by various types and colors of skin. Therefore consumers can easily get products that are suitable and suitable for their color and skin type.

In this study variable safe for skin has a low loading factor value. This is because Make Over products do not use natural ingredients completely on the product. Rahman's (2013) study found that consumer attitudes towards cosmetics varied greatly, even though they did not have halal certification, some cosmetics and toiletries companies claiming to use natural ingredients in their marketing efforts have succeeded in attracting consumers to buy their products.

5.1.2 Product Factors

The second factor which is a Make Over consumer purchasing decision based on research is the product factor. This product factor is formed from variable packaging design, practicality, outlets, and outlet arrangement. The most significant main variable in product factors is arrangement of outlets.

The arrangement of outlets is part of a store or outlet environment. Consumers feel interested in buying make over products because of the appearance of the Make Over outlet arrangement, this is in line with the results of research conducted by Hanaysha (2018) which shows that the store environment has a significant positive impact on consumer purchasing decisions. Mahmood and Khan (2014) also point out that store environments in stores allow a brand to differentiate itself from competitors. Therefore the store environment is one of the important factors that can influence a consumer's purchasing decision.

Consumers choose Make Over because Make Over products are in line with their expectations, namely attractive and easy to carry packaging. The arrangement of Make Over outlets is also one of the attractions for consumers. The product arrangement that is neat and in accordance with the type of product makes the display of stores attract consumers to buy.

5.1.3 Promotion Factors

Kumar \& Raju (2013), found that advertisements that reach and attract customers will have a greater impact on purchasing decisions. In addition, advertisements that can deliver product information clearly will make it easier for consumers to get information about products and minimize consumers switching to other product advertisements. Sharma, et al. (2013) in their research showed that most consumers affected by advertising when making choices and advertising were important factors.

The Make Over product advertisements displayed, according to consumers, are quite interesting. They argue that the advertisements that are displayed represent the skin of Indonesian women, because the model used by Make Over has a variety of skin colors. However, consumers still feel that information about the product is unclear. 5.1.4 Social Media Factors

The fourth factor that becomes consumer purchasing decisions is social media factors which include Beauty Blogger and product reviews on a website. Social media is now a tool that is widely used by everyone. In today's digital era, social media offers many conveniences. Through social media we can find various kinds of information, one of which is information about a product. Beauty blogger becomes the dominant variable in social media factors in this study, this is because Beauty Blogger is considered to have credible credibility. Beauty Blogger is currently highlighted by consumers because they usually provide comprehensive information about makeup products. This is in line with the results of research from Erkan (2015) which shows that the quality and credibility of information or information givers in social media has a positive impact on one's purchasing decisions.

Today, many websites that house or accommodate consumer reviews about a product. In the website we can find out how the rating of a product and how many consumers are satisfied and match the product. Lin, et al. (2011) found in his research that online reviews or reviews of high-quality products had a positive effect on consumers' purchase intentions, but also found that the more reviews or reviews of products would increase the popularity of these products and the more willingness to buy the product.

\subsubsection{Service Factors}

Discounts are a service that is profitable and tempting for consumers. Consumers will be more interested in buying products that provide discounts, Joelle (2017) in his research suggests that discounts are very beneficial for consumers who are still learning because it will help consumers in buying products. In this study the discount has a value of a loading factor of 0.724 not greater than the tester factor. This happens because Make Over rarely gives discounts and small discounts are around $5 \%-20 \%$.

The existence of a product tester service also helps consumer purchasing decisions because with the tester the consumer can try the product and find out whether the product is suitable or not when used by consumers. The tester in this study is the most dominant variable in the service factor. Heilman et al. (2011) found that consumers who did not have a previous plan, tried a free sample or a tester could attract and encourage consumer purchasing decisions, this was in line with the most dominant variable in the service factor, the tester. Consumers feel that they have benefited from the Make Over product tester service at Make Over outlets. Consumers feel that the existence of a tester makes it easy for them to determine which products are suitable for consumers. In addition, consumers also feel happy if they get a discount when buying a product. 
5.1.6 Factor Recommendation for Relatives

The sixth factor is a family recommendation factor which includes family recommendations and friends' recommendations. Relatives' recommendations are one of the determining or driving factors in a purchasing decision for an item, this is evidenced by Miranda (2009) in his research stating that family and group references can influence the consumption of special items such as cosmetics as long as they are in accordance with consumer desires.

Md Feaz, et al. (2014) in their study found that before buying a product, consumers tend to ask for advice or recommendations from friends. This is in line with the results of research that show that the recommendation factor is one of the determining factors and the most influential variable is the recommendation of friends in making a decision to purchase Make Over products. Many respondents said that they were affected by their friends when deciding to buy Make Over products. Their friend recommended and said that Make Over products are worth a try.

5.1.7 Trend Factor

The seventh factor formed is a trend factor which consists of trend variables and self-confidence. Trend variable is the most dominant variable in the trend factor. Trend is a factor that consumers consider in product purchasing decisions. This is because consumers do not subscribe or use a style or trend, but adopt a number of styles or trends (Johnson, 2006). Consumers buy cosmetics also follow the trend that is currently underway. Many cosmetic trends are currently taking place in Indonesia, including glossy look, dewy look, smooth coverage, and Korean look (lifestyle.bisnis.com). Therefore, consumers need cosmetic products that issue product variants that follow the current trend. Make Over wants to follow the ongoing trend, so that it becomes one of the things that is considered and attracts consumers to buy their products.

Consumers feel confident when using products that can follow the current trend. Consumers feel confident when using Make Over products, this is one of the motivations for consumers to buy Make Over products. This is in line with Ekinci and Riley (2003) who say that consumers' self-concept (self-confidence and beautiful needs) in harmony with product concepts, can be part of consumer purchasing decisions.

\subsection{Dominant Factors of Make Over Product Purchase Decisions}

The dominant factor which is the purchasing decision factor for Make Over products in this study is Perception of Product Benefits. Determination of this dominant factor is based on the highest eigenvalues of the factors that have been formed. Perception is the process when consumers choose, organize and interpret information that comes into its own meaning to create an overall picture (Kotler, 2005). The perceptions of each consumer of a product can vary, this is because each consumer receives a stimulus and interprets it differently depending on each individual.

The products offered by Make Over are cosmetic products which fall into the category of special products or Specialty goods. Specialty goods are products that have unique characteristics where consumers are willing to make a special effort to buy them (Kotler, 2008). Consumers consider the purchase decision of Make Over products, because they have the perception that they will get many benefits from Make Over products. Consumer perceptions of product benefits will have an impact on purchasing decisions and satisfaction with the product. Make Over manufacturers should be able to meet consumer expectations of the perceived benefits of the product so that consumers can remain loyal to Make Over. In essence, Make Over's consumer purchasing decisions are to benefit from the Make Over product.

\section{Conclusion}

Based on the results of research and discussion of the purchasing decision factors for Make Over products, conclusions can be drawn as follows of the 23 factors in this study, 7 factors were made to purchase Make Over products, namely: perception of product benefits, product factors, promotion factors, social media factors, service factors, relatives recommendation factors, trend factors. From the seven factors formed, perception of product benefits is the dominant factor which is a factor in purchasing decisions for Make Over products.

\section{References}

Arikunto, Suharsimi. 2006. Prosedur Penelitian: Suatu Pendekatan Praktik (Edisi Revisi 2010). Jakarta: PT Rineka Cipta.

Berkowitz, Leonard. 1989. Frustration-aggression hypothesis: Examination and reformulation. Psychological Bulletin.

Buchari. Alma, 2005. Manajemen Pemasaran dan Pemasaran Jasa. Bandung: CV. Alfabeta.

Cornwell, T.B, dkk. 2006. Sponsorship-Linked Marketing: The Role of Articulation in Memory. Journal of Consumer Research, Volume 33, Issue 3, December 2006, Pages 312-321
Ekonomi
Indonesia
Triwulan
II-2018
Tumbuh
5,27
Persen.

(https://www.bps.go.id/pressrelease/2018/08/06/1521/ekonomi-indonesia-triwulan-ii-2018-tumbuh-5-27- 
persen.html). Diakses pada 18 Agustus 2018.

Erkan, I. Evans, C. 2016. The influence of eWOM in social media on consumers' purchase intentions: An extended approach to information adoption. Computers in Human Behavior, Elsevier

Ferrinadewi, Erna. 2005. Atribut Produk yang Dipertimbangkan dalam Pembelian Kosmetik dan Pengaruhnya pada Kepuasan Konsumen di Surabaya. Jurnal Manajemen dan Kewirausahawan

Hair, et al. (2010). Multivariate Data Analyisis Seventh Edition. Pearson Prentice Hall.

Hanaysha, Jalal Rajeh. 2018. An examination of the factors affecting consumer's purchase decision in the Malaysian retail market. PSU Research Review

Heilman. Carrie, Lakishyk. Kyryl, Radas. Sonja. (2011). An empirical investigation of in-store sampling promotions. British Food Journal, Vol. 113 Issue: 10, pp.1252-1266.

Industri Kosmetik Nasional Tumbuh 20\%. (http:/www.kemenperin.go.id/artikel/18957/Industri-KosmetikNasional-Tumbuh-20). diakses pada 10 September 2018.

Kian Kinclong, $\quad$ Industri Kosmetik Nasional Tumbuh $20 \quad$ Persen. (http://www.kemenperin.go.id/artikel/18957/Industri-Kosmetik-Nasional-Tumbuh-20). Diakses pada 20 Agustus 2018.

Kotler, Philip. 2007. Manajemen Pemasaran Jilid 2. Jakarta: Indeks.

Kotler, P., \& Gary Amstrong. 2008. Prinsip-prinsip Pemasaran Edisi 12 Jilid 1. Jakarta: Erlangga.

Kotler, P. 2009. Manajemen Pemasaran. Jakarta: Erlangga.

Lin, Chin-Lung; Lee, Sheng-Hsien; Horng, Der-Juinn. 2011. The effects of online reviews on purchasing intention: The moderating role of need for cognition. Social Behavior and Personality: an international journal, Volume 39, Number 1, 2011, pp. 71-81(11)

Lu, Yonghe, Xiaohua Liu. 2018. Chinese female preference of cosmetic products information channels. Global Knowledge, Memory and Communication.

Meng-Shan Sharon Wu Isabella Chaney Cheng-Hao Steve Chen Bang Nguyen T.C. Melewar. 2015. Luxury fashion brands: factors influencing young female consumers' luxury fashion purchasing in Taiwan. Qualitative Market Research: An International Journal, Vol. 18 Iss 3 pp.

Miora Joelle. Ranosiharimandimby, Sudarmiatin and Hermawan. Agus. 2017. Analysis of Women Consumer Behavior for Purchasing "Oriflame" Cosmetic Product. Phenomenology International Journal of Academic Research in Business and Social Sciences, 2017, vol. 7, issue 6, 887-895

Nugroho. J, Setiadi. 2013. Perilaku Konsumen. Jakarta: PT. Kharisma Putra.

Prasanna Kumar. D \& Venkateswara Raju. K. 2013. The Role of Advertising in Consumer Decision Making IOSR Journal of Business and Management (IOSR-JBM) e-ISSN: 2278-487X, p-ISSN: 2319-7668. Volume 14, Issue 4 (Nov. - Dec. 2013), PP 37-45

Rangkuti, Freddy. 2002. Measuring Customer Satisfaction. Jakarta: PT Gramedia Pustaka Utama.

Schiffman, Leon G. \& Leslie L. Kanuk. 2008. Perilaku konsumen Edisi 7. Jakarta: Indeks

Semuel dkk. 2007. Perilaku Dan Keputusan pembelian pelanggan Restoran Melalui Stimulus 50\% Discount Di Surabaya.

Setiadi, Nugroho J.. 2003. Perilaku Konsumen: Konsep dan Implikasi (Untuk Strategi dan Penelitian Bisnis Pemasaran). Jakarta: Prenada Media.

Sharma. Anjali, Shruti. Bhola, Malyan. Shweta \& Patni, Neha. 2013. Impact of Brand Loyalty on Buying Behavior of Women Consumers for Beauty Care Products. Delhi: Global Journal of Management and Business Studies. ISSN 2248-9878 Volume 3, Number 7 (2013), pp. 817-824

Sriwongrat. 2008. Consumers' Choice Factors of an Upscale Ethnic Restaurant. Lincoln University.

Sugiyono. 2016. Metode Penelitian Kuantitatif, Kualitatif, dan R\&D. Bandung: Alfabeta

Sumarni, Murti dan John Soeprihanto. 2010. Pengantar Bisnis (Dasar-dasar Ekonomi Perusahaan). Edisi ke 5. Yogyakarta: Liberty Yogyakarta.

Sundrani, Deepak Murlidhar. 2018. Factors influencing home-purchase decision of buyers of different types of apartments in India. International Journal of Housing Markets and Analysis.

Swastha, Basu \& Handoko, Hani. 2011. Manajemen Pemasaran-Analisis Perilaku Konsumen. Yogyakarta: BPFE.

Thanasuta, Kandapa. 2015. Thai consumers' purchase decisions and private label brands. International Journal of Emerging Markets, Vol. 10 Issue: 1, pp.102-121

Tirelli, Christian, María Pilar Martínez-Ruiz. 2014. Influences of product attributes on sojourners' food purchase decisions. British Food Journal, Vol. 116 Iss 2 pp. 251 - 271

Uddin, M. R., Lopa, N. Z., \& Oheduzzaman, M. Factors affecting customers'buying decisions of mobile phone. khulna city, bangladesh: International Journal of Managing Value and Supply Chains 5 (2), 21

Usman, Hardius, \& Nurdin Sobari. 2013. Aplikasi Teknik Multivariate untuk Riset Pemasaran. Jakarta: Raja Grafindo Persada.

Weber, J. M., \& Capitant de Villebonne, J. 2002. Differences in purchase behavior between France and the USA: the cosmetic industry. Journal of Fashion Marketing and Management Vol.6 No.4 
Wasitaatmadja, M.S, 1997. Penuntun Ilmu Kosmetik Medik, Universitas Indonesia, Jakarta.

Wen, Ivan. 2009. Factors affecting the online travel buying decision. International Journal of Contemporary Hospitality Management, Vol. 21 Issue: 6, pp.752-765

Zulkarnain, Zella Aziza. 2017. Pengaruh Positioning Produk Terhadap Minat Beli Make Over di Kota Bogor. Institut Pertanian Bogor 